\title{
A humán agyi aktivitás hálózatelemzési modellezése - Humán agyi hálózatok
}

\author{
Tóth Brigitta*, Boncz Ádám*, File Bálint, Winkler István, Molnár Márk \\ Természettudományi Kutatóközpont, Kognitív Idegtudományi és Pszichológiai, \\ Hang- és Beszédészlelési Kutatócsoport, Budapest
}

Beérkezett: 2020. szeptember 14.; Elfogadva: 2020. november 02.

\begin{abstract}
Összefoglalás
A hálózatkutatás idegtudományi alkalmazása áttörő eredményt hozott a humán kogníció és a neurális rendszerek közötti kapcsolat megértésében. Jelen tanulmány célja a neurális hálózatok néhány kutatási területét mutatja be a laborunkban végzett vizsgálatok eredményein keresztül. Bemutatjuk az agyi aktivitás mérésének és az agyi területek közötti kommunikációs hálózatok modellezésének technikáját. Majd kiemelünk két kutatási terület: 1) az agyi hálózatok életkori változásainak vizsgálatát, ami választ ad arra, hogy hogyan öregszik az emberi agy; 2) az emberi agyak közötti hálózat modelljének vizsgálatát, amely a hatékony emberi kommunikáció idegrendszeri mechanizmusait próbálja feltárni. Tárgyaljuk a humán kommunikációra képes mesterséges intelligencia fejlesztésének lehetőségét is. Végül kitérünk az agyi hálózatok kutatásának biztonságpolitikai vonatkozásaira.
\end{abstract}

Kulcsszavak: elektrofiziológia, gráfelmélet, humán neurális fejlődés, humán kommunikáció

\section{Modelling the human brain activity}

\author{
Brigitta Tóth*, Ádám Boncz*, Bálint File, István Winkler, Márk Molnár
}

The Research Centre for Natural Science, Research Centre for Natural Sciences,

Institute of Cognitive Neuroscience and Psychology, Sound and Speech Perception Research Group, Budapest, Hungary

\section{Summary}

The human brain consists of 100 billion neurons connected by about 100 trillion synapses, which are hierarchically organized in different scales in anatomical space and time. Thus, it sounds reasonable to assume that the brain is the most complex network known to man. Network science applications in neuroscience are aimed to understand how human feeling, thought and behavior could emerge from this biological system of the brain. The present review focuses on the recent results and the future of network neuroscience. The following topics will be discussed:

Modeling the network of communication among brain areas. Neural activity can be recorded with high temporal precision using electroencephalography (EEG). Communication strength between brain regions then might be estimated by calculating mathematical synchronization indices between source localized EEG time series. Finally, graph theoretical models can describe the relationship between system elements (i.e. efficiency of communication or centrality of an element).

How does the brain age? While for a newborn the high plasticity of the brain provides the foundation of cognitive development, cognition declines with advanced age due to so far largely unknown neural mechanisms. In one of our studies, we demonstrated that there is a correlation between the anatomical development of the brain (at prenatal age) and its network topology. Specifically, the more developed the baby's brain, the more functionally specialized/ modular it was. In another study we found that in older adults, when compared to young adults, connectivity within modules of their brain network is decreased, with an associated decline in their short-term memory capacity. Moreover, Mild Cognitive Impairment patients (early stage of Alzheimer) were characterized with a significantly lower level of connectivity between their brain modules than the healthy elderly.

*A szerző́k egyenlő mértékben járultak hozzá a publikációhoz. 
Human communication via shared network of brain activity. In another study we recorded the brain activity of a speaker and multiple listeners. We investigated the brain network similarity across listeners and between the speaker and listeners. We found that brain activity was significantly correlated among listeners, providing evidence for the fact that the same content is processed via similar neural computations within different brains. The data also suggested that the more the brain activity synchronizes the more the mental state of the individuals overlap. We also found significantly synchronized brain activity between speaker and listeners. Specifically l) listeners' brain activity within the speech processing cortices was synchronized to speaker's brain activity with a time lag, indicating that listeners' speech comprehension processes replicated the speaker's speech production processes; and 2) listeners' frontal cortical activity was synchronized to speaker's later brain activity, that is, listeners preceeded the speaker, indicating that speech content is predicted by the listeners based on the context.

Future challenges. Future research could target artificial intelligence development that is capable of human-like communication. To achieve this, the simultaneous recording of brain activity from listener and speaker is needed together with efficiency of the communication. These data could be then modelled via AI to detect biomarkers of communication efficiency. In general, neurotechnology has been rapidly developing within and outside of research and in clinical fields thus it is time for re-conceptualizing the corresponding human right law in order to avoid unwanted consequences of technological applications.

Keywords: electrophysiology, graph theory, human neural development, human communication

\section{Bevezetés}

Az élet számos területén léteznek úgynevezett komplex rendszerek, amelyek - annak ellenére, hogy rendkívül nagy elemszámú komponensből állnak - képesek összehangolt, azaz szinkronizált múködésre. Ilyen rendszerként múködik például az internet, az emberi kapcsolatok hálózata vagy akár az elektromos villamoshálózat is. Az ilyen komplex rendszerek egyik legfontosabb jellemzője, hogy nincsen egy, a felépítésében a többi elemtől eltérő, központi elem, amely felelős a rendszer irányításáért. Az elmúlt 30 év áttörő eredményei a fizika területéról (ld. Watts-Strogatz 1998; Barabasi-Albert 1999) megalapozták a komplex hálózatok komponenseinek és az azok közötti kapcsolatoknak a formális matematikai leírását, modellezését. Így mára már lehetôség nyílik az eddig ismeretlen rendszerek múködési mechanizmusainak a megértésére, sőt, akár azok jövőbeli viselkedésének elörejelzésére is (Albert-Barabási 2002). Jelen tanulmányban a humán idegrendszer komplex hálózati kutatási területének eredményeit és jövőjét tekintjük át.

\section{A humán agyi hálózatok modellezése: az agy ujjlenyomatának módszere}

Az emberi agy 100 milliárd idegsejtet és azok közötti legalább 100 billió kapcsolatot (szinapszist) fogalal magába, amelyek hierachikus módon szerveződnek számos anatómiai és idói skálán. Ezért az emberi idegrendszer az ember számára ismert egyik legkomplexebb rendszer, amely ennek megfelelően számos téri és idői szinten vizsgálható. A legkisebb elemi szint az idegsejtet alkotó molekulák közötti interakció hálózata, amelynek vizsgálata segíthet megérteni a génexpresszió téri-idői mintázatainak alakulását, így feltárhatja a genetikai alapú megbetegedések, így például a skizofrénia vagy autizmus mechanizmusát is. A mikroszkopikus neuronok közötti szinaptikus kapcsolatrendszer és a makroszkopikus agy- területek közötti strukturális-anatómiai vagy dinamikusfunkcionális összeköttetések, hálózatok modelljei lehetővé teszik, hogy statisztikai és kauzális összefüggéseket tárjunk fel az emberi viselkedés és a neurális rendszer között. Sőtt, akár több ember agyi aktivitása is egy komplex hálózatként vizsgálható, amely az emberi szociális képesség megértését is elősegítheti.

Nem invazív módon az agyi aktivitás nagyon jó idői felbontásban (milliszekundumos pontosság) például az ún. elektroencephalográfiai (EEG) eszközzel mérhető. Ez - nyugalmi vagy feladathelyzetben - az emberi fejre helyezett elektródák segítségével történik (ld. 1. ábra A). Az így elvezetett jelből forrás-lokalizációs eljárások segítségével visszaállítható a makroszkopikus agyi régiók (például egyes gyrus-ok, pl. inferior frontális gyrus, stb.) időbeli aktivitása. Az agyi régiók közötti kommunikáció (interakció) intenzitásának meghatározása az agyi jelek közötti matematikai hasonlóság (szinkronizáció) módszereivel becsülhető meg. Elektrofiziológiai jelek közötti szinkronizáció számos módszerrel mérhetô, de a térfogatvezetésből fakadó látszólagos kapcsolatok okozta mérési hibák csökkentése érdekében leggyakrabban fázisszinkronizációs eljárást alkalmaznak (Toth et al. 2017). Az általános feltételezés szerint minél nagyobb a fázisszinkronizáció mértéke két neuron populáció között, annál nagyobb az információáramlás mértéke is. Az 1 . ábra B) paneljében egy így elóállított, agyi területek közötti funkcionális kapcsolati hálózat látható. Ebben a hálózatban az egyes makroszkópikus agyterületek felelnek meg a hálózat csomópontjainak (pl. frontális kéreg egyes részei), míg a hálózati csomópontok közötti kapcsolatokat (gráfelméleti megnevezése alapján út) a neurális szinkronizáció - időben változó - erőssége határozza meg. A hálózat strukturális múködése - más néven topológiája - gráfelméleti (komplex hálózati) mutatók segítségével jellemezhető (lásd 1 . ábra $C$ panelje). Például mérhetô az információáramlás hatékonysága (ún. kapcsolat útjának hossza), azonosítható rendszer központi 


\section{A) Agyi aktivitás mérési technikája}

Magas idői felbontású elektrofiziológiai aktivitás
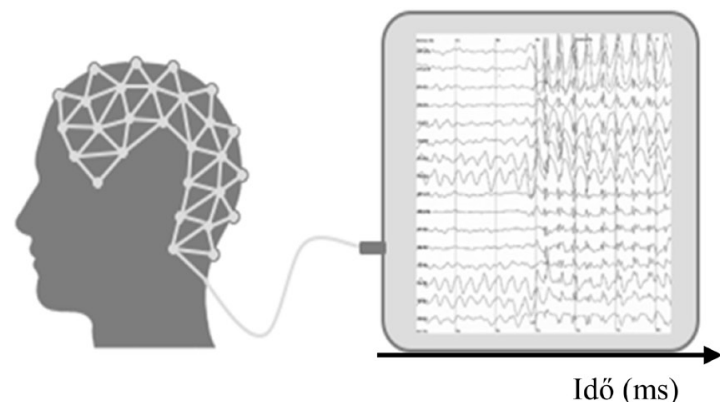

\section{B) Funkcionális konnektivitás elemzés}

Agyi régiók közötti kommunikációs kapcsolatok dinamikus rendszere

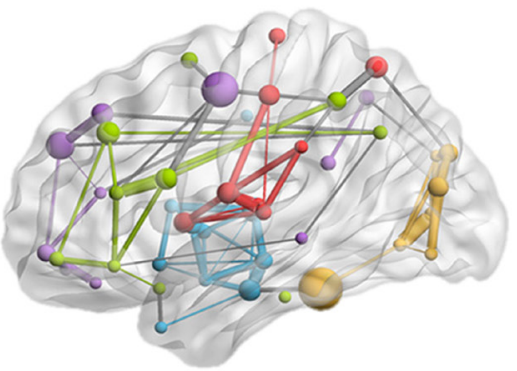

C) Komplex hálózati elemzés

Lokális topológia
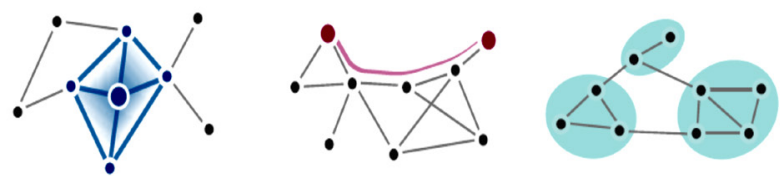

1. ábra

\begin{abstract}
Az agyi aktivitás mérésének és agyterületek közötti kapcsolathálózat modellezésének sematikus ábrája.

A) Az agyi aktivitás mérése EEG segítségével. B) Agyi területek közötti funkcionális kapcsolatok hálózata. A pontok az agyi ré giók centrális koordinátáit jelölik, míg a köztük lévő vonalak szignifikáns funkcionális kapcsolatokat. Az egyes vonalak vastagsága a kapcsolat erősségének függvénye. C) Gráfelméleti hálózatelemzési módszerek. A pontok a hálózati csomópontokat, a vonalak a hálózat csomópontjai közötti kapcsolatokat jelölik A hálózatelméleti mutatókat az alábbi csoportokba sorolhatjuk: (1) lokális topológiai mutatók (pl. centralitási mutató); (2) út/ távolság mutatók; és (3) modularitás mutatók.
\end{abstract}

elemei (ún. centralitás mutatókkal csomópontok funkcionális szerepe a rendszer múködésében) vagy az alrendszerek/modulok szerveződése is.

\section{Az agyi hálózatok életkori változásai: hogyan öregszik az emberi agy?}

Az újszülött és általánosságban gyermek központi idegrendszere rendkívüli módon képes az anatómiai és funkcionális változásra (úgynevezett neuronális plaszticitásra). A neurális plaszticitás az idegrendszer funkcionális fejlődésének alapköve (Cicchetti-Curtis 2006), de akár a felnőtt idegrendszerben is lejátszódik, így lehetővé téve a külső és belső ingereknek megfelelő alkalmazkodást. Ilyen például a szinapszisok képződése, illetve azok strukturális átrendeződése, agysérülések utáni axon terminális növekedés (Kállai et al. 2008). Kutásunkban azt a feltételezést teszteltük, hogy magzati és újszülöttkori rendkívül gyors anatómiai és funkcionális fejlódés vajon mérhető-e az agyi hálózatok szerveződésének változásával.

Ebben a kutatásunkban 138 újszülött (életkoruk 1-4 nap) nyugodt alvás fázisban rögzített agyi aktivitását vizsgáltuk (Tóth et al. 2017). Random hálózat matematikai modell alapján létrehozott hálózatot (Erdősi-Rényi modell) összehasonlítva az újszülött agyi hálózattal azt állapítottuk meg, hogy az agyterületek közötti kommunikáció már a születés pillanatában nem-véletlenszerúen szerveződik: néhány régió kiemelkedik és központi szerepet tölt be a hálózaton belüli információáramlás szerveződésében (mint például, ahogy a Barabási-Albert modell sugallja ld. 2. ábra $A$ ). Regressziós statisztikai modellek segítségével azt is kimuttattuk, hogy az agyi hálózatok a magzati fejlődés utolsó néhány hetében (3642 hét) - feltételezhetően az agy anatómiai-strukturális fejlődésének következtében - fokozatosan átalakulnak

A) Újszülött agyi hálózat elemzésére használt hálózati modelek

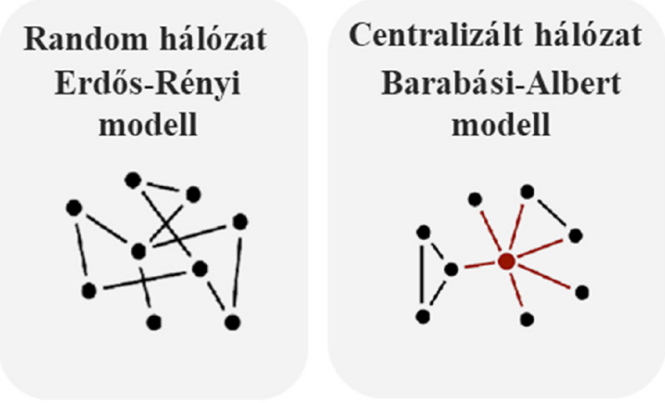

B) Magzati életkor és az agyi hálózati struktúra közöti statisztikai összefüggés

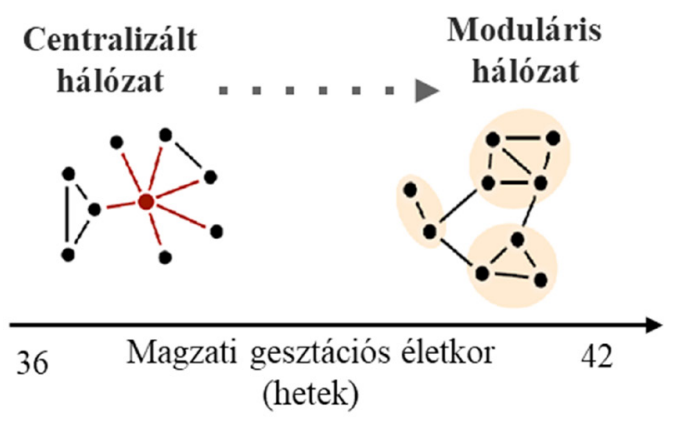

2. ábra $\quad$ Az újszülöttkori agyi hálózatok vizsgálatának eredményei

A) Egy random (pl. Erdős-Rényi model alapján) és egy centralizált hálózati szerveződés (Barabási-Albert model alapján) sematikus ábrárolása B) A magzati életkor és a hálózati szerveződési minta összefüggésének sematikus összefoglalása. 
(ld. 3. ábra B). Specifikusan a kevés központi régió müködésének a dominanciája helyett jellemzóbbé válik az agyi régiók csoportjainak (alrendszereinek) együttmúködése. Ez az agyi régiók funkció szerinti specializációját jelezheti (az agy ún. funkcionális modulokba szerveződve múködik). Általánosságban a hálózat modularitásának

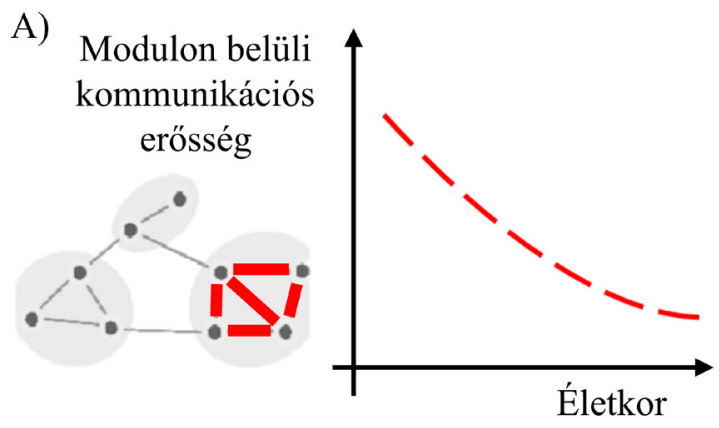

B) Az agyi régiók modulon belüli kapcsolati erőssége fiatal és idős személyekben

Fiatal

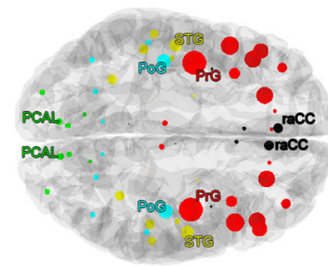

Frontális lebeny

- Modulon belüli kapcsolat erősség

C)

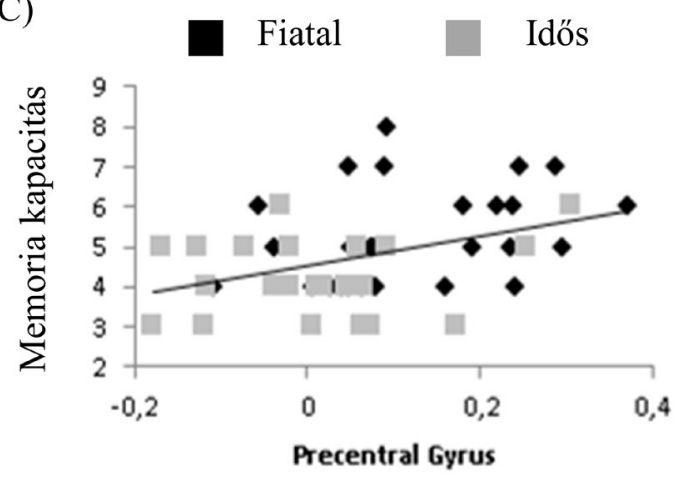

Modulon belüli kapcsolat erösség

3. ábra

Az idős és fiatalkori agyi hálózatok szerveződésének vizsgálat eredményei.

A) Az idős korcsoportban csökkent az agyi hálózat moduljain belül az agyterületek közötti kommunikáció erőssége. B) Az agy felülnézetből van ábrázolva. Az agyterületeket pontok jelölik. A modulon belüli kapcsolat erósségét a pont mérete határozza meg, a pont színe a kortikális lebenyt jelzi. C) Precentrális agyi régió modulon belüli kapcsolati erôssége a mért memória kapacitás függvényében idős (szürke négyzet) és fiatal (fekete négyzet) vizsgálati személyek esetében. növekedése csökkenti a hálózat múködésének komplexitását, de lehetővé teszi a parallel információ feldolgozást (a modulok mint párhuzamos információfeldolgozási egységek múködnek együtt), és így valószínúleg optimálisabb rendszer múködést biztosít.

Az öregedés természetes folyamata a központi idegrendszer idegsejtjeinek pusztulásával együtt sokszor együtt jár bizonyos kognitív képességek hanyatlásával, ilyen például a perceptuális vagy tanulási képesség csökkenése. Idős korban olyan központi idegrendszeri betegségek jelentkezhetnek, amelyek az emlékezet lassú elvesztésével, illetve mozgászavarokkal járnak (Alzheimerkór, Parkinson-kór; Cabeza-Nyberg-Park 2016). Egyrészt azt feltételeztük, hogy az agyi hálózatok átszerveződése követi az időskori emlékezeti képességek hanyatlását (ld. 2. ábra). Nemrég végzett kutatásunkban azt teszteltük, hogy az időskori agyi hálózatok átszerveződése és múködése mennyire képes bejósolni az időskori kognitív képességek romlását.

Ebben a vizsgálatunkban fiatal $(\mathrm{N}=22$; életkor $=22.4$ $\pm 3.1)$ és idős $(\mathrm{N}=26$; életkor $=66.3 \pm 3.9)$ felnőttek nyugalmi helyzetben mért agyi aktivitásának szerveződését hasonlítottuk össze (File et al. 2020). Itt már specifikusan az agyi hálózatok moduláris múködését vizsgáltuk. Az idős felnőttek agyi hálózatainak modularitása általánosságban magasabb volt a fiatal felnőttekhez képest, de annak az árán, hogy az egyes agyi hálózati modulokon belül az agyterületek közötti kommunikáció erôssége csökkent (ld. 3. ábra $A$ ). A hálózati modulokon belüli kommunikáció gyengülése az időseknél leginkább a frontális agyi területeket érintette (ld. 4. ábra B). Ehhez az agyterülethez köthető a legtöbb morfológiai és funkcionális időskori változás is.

Az idősek emlékezeti teljesítménye nemcsak szignifikásan alacsonyabb volt a fiatalhoz képest, de korrelációs statisztikai modell segítségével összefüggést mutattunk ki az emlékezeti képesség és az agyi modulon belüli

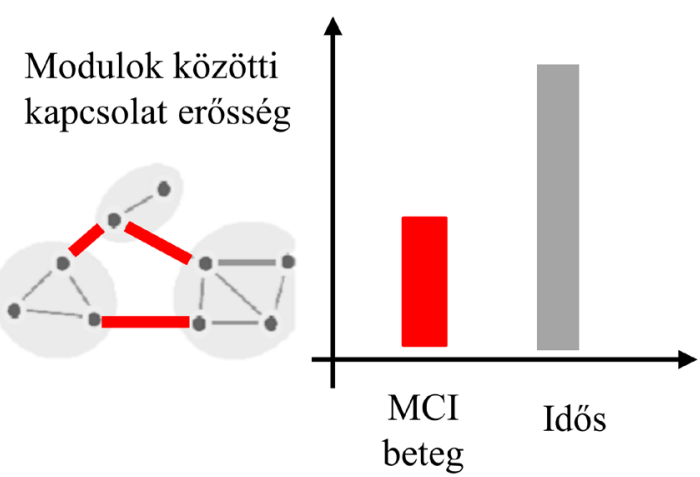

4. ábra

Az enyhe demens idős betegek és egészséges idősek agyi hálóza ti vizsgálatának eredményei.

A hálózatok moduljai között mérhető kommunikáció erőssége csökkent a betegcsoportban az egészséges idősekhez képest. A) A verbális kommunikációs helyzet sematikus ábrája. B). A verbális információt hallgató személyek agyi aktivitása közötti szinkronizáció. A szinkronizáció mértékét az egyes agyterületeken a színskála jelöli. 
kommunikációs erősség között. Például az egyik frontális régió (precentralis gyrus) modulon belüli kapcsolati erőssége előre jelezte az egyéni emlékezeti teljesítményét (ld. 3. ábra $C$ ). Tehát minél alacsonyabb volt valakinek agyi modulon belüli összekapcsoltsága, annál alacsonyabb volt a megfigyelt emlékezeti képessége is.

További kutatásunkban egészséges idős $(\mathrm{N}=19 ; 60$ 70 év között) és enyhe demenciával járó idős betegcsoport (ún. "mild cognitive impaired" enyhe kognitív zavar $\mathrm{N}=14 ; 60-70$ év között) agyi hálózatainak múködését vizsgáltuk (Toth et al. 2013). Agyi modulok között csökkent kommunikáció volt kimutatható az egészséges idősekhez képest az idős betegek agyi múködésében.

Összegzésképpen elmondható, hogy újszülött korban az agyi hálózatok korai funkcionális specializációja figyelhető meg. Majd az öregedés az agyi hálózatok moduljain belüli kommunikáció hanyatlásával jár. Időskori központi idegrendszeri patológia esetben - az MCI betegeknél - már a modulok közötti kommunikációra is csökkent, amely feltételezhetően csökkent szellemi képességet von maga után. Az agyi hálózatok szerkezetének változása az életút során az idegrendszer funkcionális kapacitásának modelle lehet, így lehetőséget teremthet akár a csökkent mentális képességek monitorozására, vagy akár előrejelzésére és prevenciójára. Feltételezésünk szerint az egyéni agyi hálózatok feltérképezésével lehetőség lenne akár egyénre szabott agyi stimulációt is végezni. Például az adott személynél leginkább érintett agyi kapcsolatok mesterséges stimulációja (pl. tDCS használatával) akár megelőző vagy akár terápiás hatású is lehet.

\section{Az agyi hálózatok közötti információáramlás: az emberi kommunikáció neurális hálózati modellje}

Rendkívül nagy előrelépés lenne tudományos innováció területén egy olyan technológia feltalálása, amely képes mérni egy adott személy érzelmi állapotát, gondolatát, emlékeit és majd azt közvetíteni ugyanabban a formában egy másik ember tudatába. Ez a technológia már létezik - ez nem más, mint a humán, fóként verbális, kommunikáció. Bár a humán kommunikáció tudományos szemmel egy rendkívül komplex, megoldatlan információfeldolgozási probléma (ld. a legmodernebb gépi asszisztensek jelenlegi szintjét, mint például automatikus fordító és szövegelemző software-ek), az emberek - látszólag mégis minden erőfeszítés nélkül, egy pillanat alatt képesek megérteni egymást, azaz közel azonos fogalmi/ affektív tartalmat egymás tudatában megjeleníteni. Ez a képesség az alapja minden humán interakciónak és így előfeltétele minden kooperatív viselkedésünknek, tehát mindennek, ami az embert igazán megkülönbözteti az állatvilágtól. A probléma komplexitását az is jelzi, hogy máig nem sikerült előállítani hatékony, emberéhez hasonló kommunikációra képes mesterséges intelligenciát. Jó példa erre bármelyik ügyfélszolgálati “chatbot” vagy gépi asszisztens alkalmazás (Siri, Cortana, etc.), amely kétértelmú üzenetre értetlenné válik és gyakran a beszélgetés közös kontextusába nem illő, meglepő módon válaszol. A probléma egyik potenciális megoldását az jelentheti, ha megfejtjük azokat a mentális és neurális mechanizmusokat, amelyek részt vesznek az emberi kommunikációban.

Ennek megfelelően egy újszerü, de jelentős kutatási terület a hatékony emberi kommunikáció idegrendszeri mechanizmusainak feltárására fókuszál az emberi agyak közötti egységes hálózatok modellezésével (összefoglalásként lásd Hasson et al. 2012). Legújabb vizsgálatunkban verbális kommunikációs helyzetben követtük egy beszélő személy és az ő beszédét hallgatók agyi hálózatai közötti hasonlóságot (Boncz et al. 2020). EEG segítségével mértük mind a hallgatók $(\mathrm{N}=26)$, mind a beszélő $(\mathrm{N}=1)$ személy agyi aktivitását, miközben a beszélő összefüggő történetet mondott el. Elsőként a hallgatók agyi aktivitásának hasonlóságát vizsgáltuk az egyes agyi

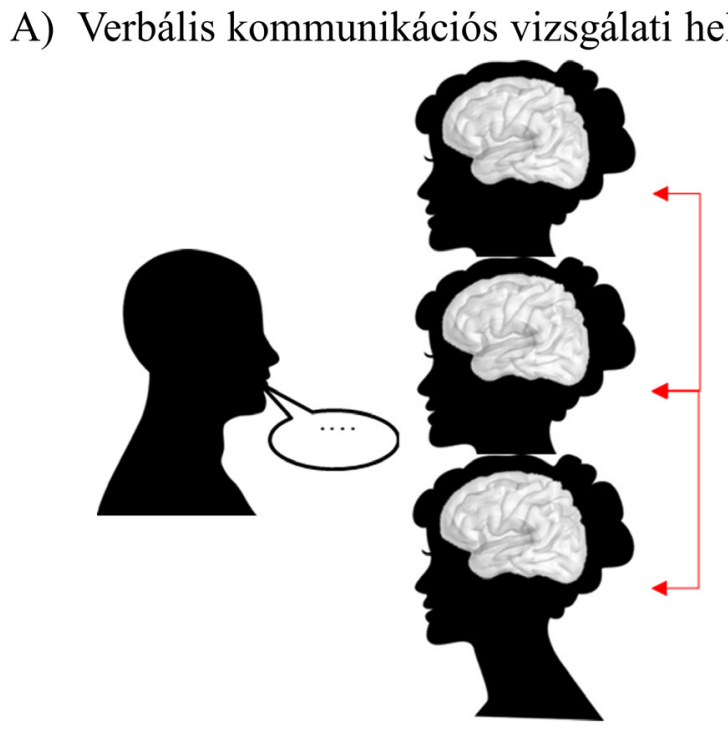

B) Hallgatók közötti neurális szinkrozáció

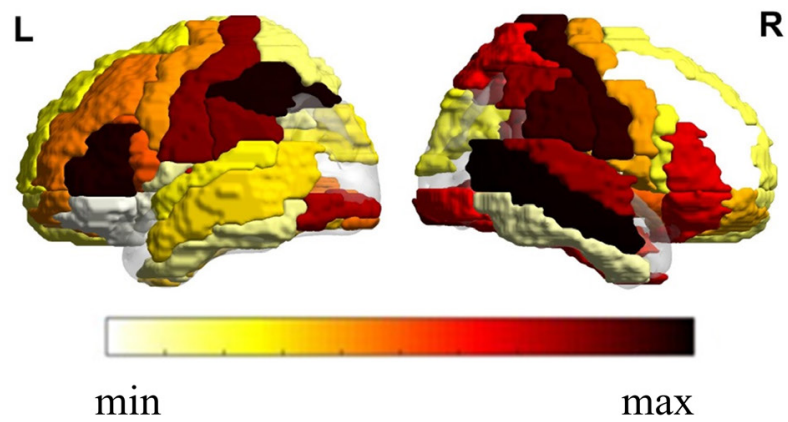

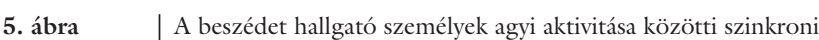
záció.

A) A verbális kommunikációs helyzet sematikus ábrája. B). A verbális információt hallgató személyek agyi aktivitása közötti szinkronizáció. A szinkronizáció mértékét az egyes agyterületeken a színskála jelöli. 
régiókban (ld. 5. ábra). Eredményeink alapján általánosságban elmondhatjuk, hogy azonos verbális információ feldolgozása azonos neurális aktivitással jár együtt, amely legnagyobb mértékben a beszédfeldolgozásra specializálódott agyi területeken (például inferior frontális vagy supramarginalis agykérgi területek) és a komplex multimodális vagy emlékezeti tartalmakat feldolgozó agyi régiókban (mediális temporális vagy inferior parietális kéreg) volt kimutatható. Más szóval: a verbális kommunikáció, mint inger, kimutathatóan hasonló aktivitást vált ki az azt hallgató személyekből az agyi régiók egy kiterjedt hálózatában. Feltételezzük (de jelenlegi adataink alapján még nem állapíthatjuk meg biztosan), hogy minél jobban átfed két, azonos beszédet hallgató személy mentális állapota (pl. ahogyan értelmeznek egy többértelmú leírást), annál hasonlóbb a két személy neurális rendszerének aktivitása is - ezt a feltételezést további kísérletekkel próbáljuk még alátámasztani vagy cáfolni.

Ezt követően arra voltunk kíváncsiak, hogy milyen mértékű hasonlóság figyelhető meg a beszélő és a hallgatók agyi aktivitása között (ld. 7. ábra). Ebben az esetben kétféle időskálán érdemes neurális szinkronizációt mérni. Elsősorban azt vártuk, hogy minél jobban megérti/ dekódolja a hallgató a beszélő által mondottakat, annál inkább tükrözi a hallgató agyi aktivitása a beszéló agyi aktivitását. Az ezt reflektáló, a beszélővel szinkronizált agyi aktivitás a hallgató fejében azonban - értelemszerúen - a beszélőhöz képest valamekkora idókésleltetéssel jelenik meg. Ez megfeleltethető annak, hogy a hallgató beszédmegértési folyamatai szekvenciálisan követik időben a beszélő produkciós folyamatait (ld. 6 . ábra $A$ ). Ezt alátámasztva, jelentốs neurális szinkronizáció volt megfigyelhető a beszéló és hallgató között, amikor a hallgató neurális aktivitását késleltetve hasonlítottuk össze a beszélő agyi aktivitásával. Ez a típusú szinkronizáció - elvárásoknak megfelelően - a beszédmegértésre specializálódott agyi területeken (például inferior frontális kéreg) jelent meg legerősebben. Másodsorban, számos elméleti megfontolás és empirikus eredmény támasztja alá a predikció (elvárás) szerepét a beszédmegértésben. Leegyszerüsítve, feltételezhetjük, hogy - hasonlóan más, akár elemi ingerek feldolgozásához - a beszédet hallgató személy idegrendszere folyamatosan prediktálja a soron következő hangokat, szótagokat, és általában a cselekményt is. És amikor a hallgató prediktálja, hogy a beszélgetőpartnere mit fog mondani, akkor az agyi aktivitása nem időben késleltetve mutat szinkronizációt a beszélő agyi aktivitásával, hanem időben ugyanakkor, vagy akár a beszélőt időben megelőzve. Ennek megfelelően azt is teszteltük, hogy a beszélő agyi aktivitása egyes régiókban időben késleltetve szinkronizálódott-e a hallgatók agyi aktivitásához (ld. 6. ábra B). Az eredményeink szerint igen: a frontális területek aktivitása a hallgatókban megelőzte a beszélőt, alátámasztva az elképzelést, miszerint egy beszélgetés során folyamatosan monitorozzuk, hogy mi lehet a következő legvalószínúbb információ, amit a beszélő közölni szeretne (lásd még Hasson et al. 2012).
A) Hallgató időben késletett agyi aktivitásának szinkronizációja a beszéló agyi aktivitsásához

Hallgató agyi aktivitása T időpillanatban n késleltetéssel
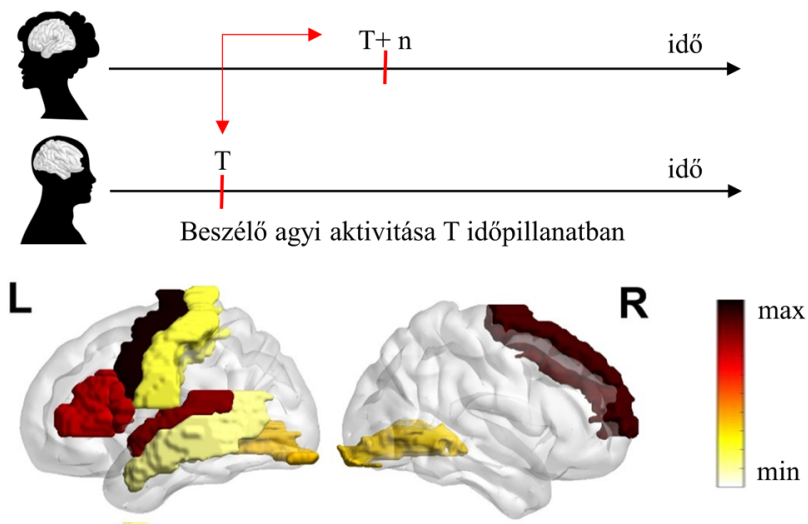

B) Beszélő időben késletett agyi aktivitásának szinkronizációja a hallgató agyi aktivitsásához
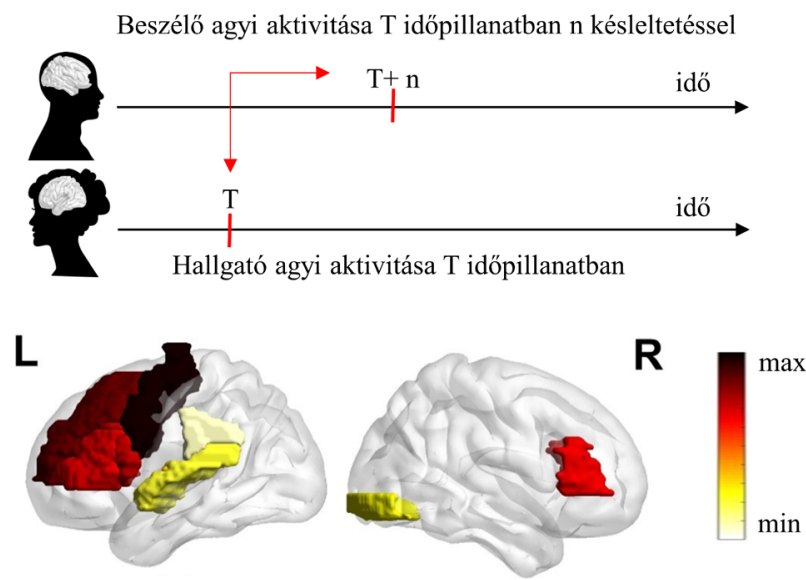

6. ábra A beszédet hallgató és a beszélő személy agyi aktivitása közötti
szinkronizáció.
A) A hallgatók agyi aktivitásának késleltetett szinkronizációja a
beszélő agyi aktivitásával. A szinkronizáció mértékét az egyes
agyterületeken a színskála jelöli. B) A beszélő agyi aktivitásának
késleltetett szinkronizációja a hallgatók agyi aktivitásával.
A szinkronizáció mértékét az egyes agyterületeken a színskála
jelöli

\section{A kommunikáló mesterséges intelligencia jövője, és biztonságpolitikai vonatkozásai}

A jövő technológiája alkalmazhatja a fent bemutatott eredményeket például, olyan mesterséges intelligencia fejlesztéséhez, amely a kommunikáció humán neurális mechanizmusainak elvei alapján épül fel, és így akár az emberi kommunikációhoz hasonló hatékonysággal múködhet.

Ennek eléréséhez a jövőbeni kutatások során természetes kommunikációs helyzetekben, és nagy idői és téri felbontásban kell mérniük 1) kommunikáló személyek neurális hálózatai közötti szinkronizáció alakulását; és 2) a verbális és non-verbális kommunikáció pillanatnyi hatékonyságát. Ezeket az információkat egy komputációs 


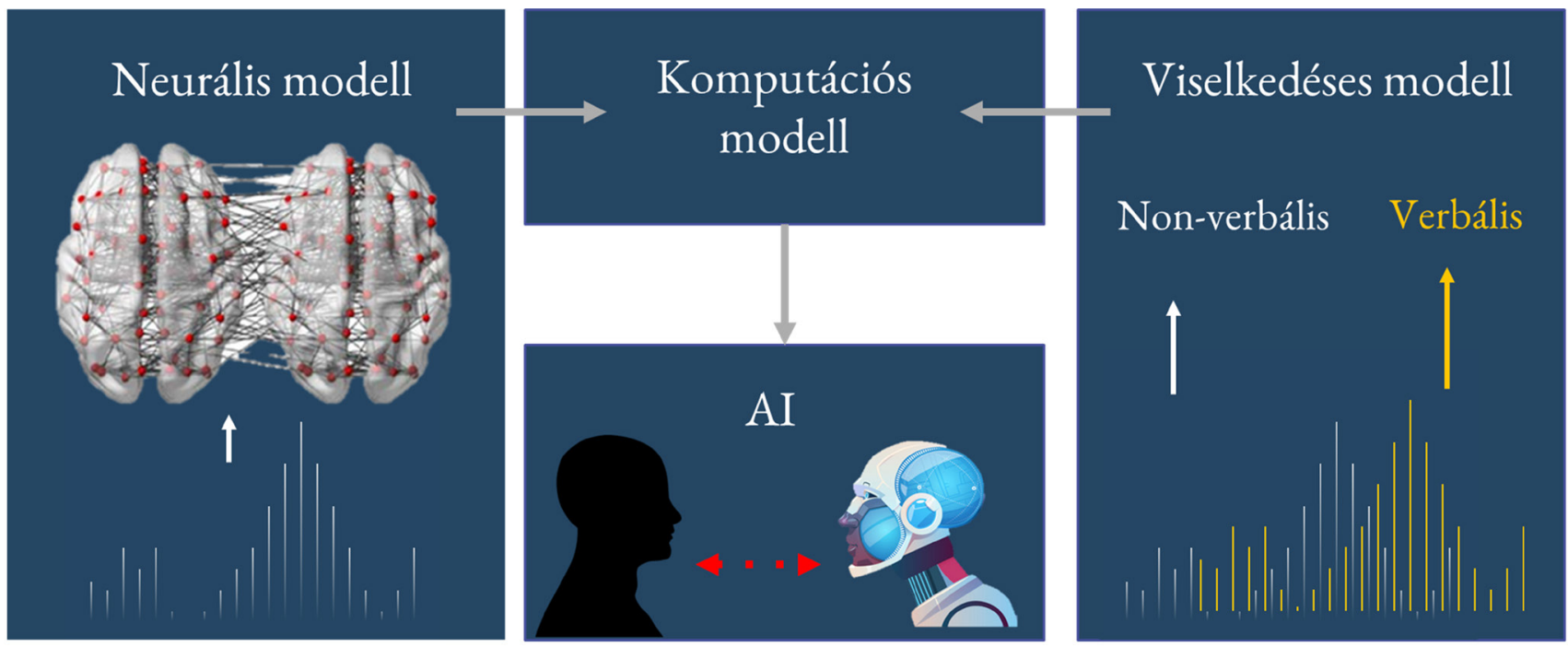

7. ábra $\quad$ A humán kommunikáció neurális és viselkedéses időbeli adatait elemző komputációs modell és annak eredményeit felhasználó mesterséges intelligen cia fejlesztésének lépéseit ábrázoló sematikus ábra

modellben lehet integrálni, és ezáltal egy olyan komplex modellt építhetnénk fel, amely képes monitorozni és imitálni az emberi kommunikáció mechanizmusait (az elképzelés sematikus bemutatása a 7 . ábrán látható).

Általánosságban rendkívüli módon megnövekedett a neurotechnológiák kapacitása az emberi kognitív képesség, intenció, vagy attitűdök mérésében. Például most már a kutatók képesek dekódolni/visszaállítani az agyi jelekből a korábban hallott beszédet (összefoglalásképpen lásd pl. Ienca-Andorno 2017). Egy másik vizsgálati helyzetben például azt kérték a résztvevőktől, hogy döntsék el, hogy a következő lépésben összeadni vagy kivonni szeretnék a számokat és várjanak egy kevés ideig mielőtt elvégzik a számolást. A várakozás ideje alatt rögzített agyi aktivitásból 70\% feletti pontossággal volt megjósolható a döntés. Más tanulmány funkcionális különbségeket tudott azonosítani a vizsgálati személyek agyi aktivitásában attól függően, hogy demokrata vagy republikánus szavazók voltak (összefoglaló tanulmányként ld. Ienca-Andorno 2017). Legújabban az úgynevezett neuromarketing területén is sikerült azonosítani eltérő marketing stratégiák által kiváltott agyi válaszokat. Ezen a területen újabban a Google, Disney vagy CBS is elindított kutatás-fejlesztési vizsgálatokat. Agyi aktivitás használható ma már elektronikus készülékek múködtetésére a játék, marketing vagy akár a kommunikáció céljából is. Például az iPhone XWave headset már alkalmazható az agyi aktivitás bizonyos szintű monitorozására, ugyanakkor a Samsung az agyi aktivitás segítségével szeretné irányíthatóvá tenni a számítógéses perifériákat (billentyüzet, egér).

A neurotechnológia másik lehetséges innovációs iránya az emberi viselkedés előrejelzése. Meglepő eredményt hozott egy elítéleteket vizsgáló utánkövetéses vizsgálat, amely az emberek agyi aktivitásának mérése alapján előre tudta jelezni, hogy a következő 4 évben melyik elítélt fog ismételten bűncselekményt elkövetni (Ienca-Andorno 2017). Ugyanakkor annak ellenére, hogy mennyire alacsony a megbízhatósága, még mindig számos búnügyi hivatal alkalmaz hazugságdetektoros (polográf) technológiát. Viszont a legújabb generációs hazugságdetektor, mely EEG és fMRI technikával kapcsol össze, sokkal megbízhatóbb eredményt ad (ez is még csak 90\% valószínűséggel becsül jól). Sőt olyan vizsgálatot is közöltek már, amely az agyi aktivitási adatok alapján 94\%-os bizonyossággal tud személyazonosítást végezni (Ienca-Andorno 2017).

Következésképpen elmondható, hogy a neurotechnológiák fejlesztése és alkalmazása is nagyon gyors tempóban fejlődik a klinikai és kutatási területeken kívül is. Amellett, hogy a társadalmi hasznossága megkérdőjelezhetetlen, az új technológia etikai és jogi vonatkozásai jelenleg teljes mértékben tisztázatlanok. Az neurotechnológia használatának kollaterális következményei és kockázatai miatt (beleegyezés nélküli agyi aktivitás mérése/elemzése vagy megkérdőjelezhető fizikai vagy mentális mellékhatásai a neurotechnológia orvosi alkalmazásának) az emberi jogi szabályozás újrafogalmazása vagy neuro-specifikus jogok létrehozása elkerülhetetlen. Például a mentális integritással az EU Alapjogokat tartalmazó fejezetének harmadik cikke foglalkozik, melyben a mentális egészség megőrzésére vonatkozó jogok már definiáltak. Ugyanígy a genetika-specifikus emberi jogi törvények fejlesztése is folyamatban van. Ezen törvények utána alkalmazhatóak lehetnének más jogi szinteken is, például a nemzetközi humanitárius törvények vagy büntetőjogi törvények tulajdonjogi törvények vagy fogyasztóvédelmi törvények is. 


\section{Irodalom}

Albert, R., \& Barabási, A. L. (2002) Statistical mechanics of complex networks. Reviews of modern physics, 74(1), 47.

Barabasi A. L., Albert R. (1999) Emergence of scaling in random networks. Science 286: 509-512.

Bassett, D. S., \& Sporns, O. (2017) Network neuroscience. Nature neuroscience, 20(3), 353.

Boncz, Á., Tóth, B. Winkler, I. Brain synchronization correlates of human communication (in preparation)

Cabeza, R., Nyberg, L., \& Park, D. C. (Eds.) (2016) Cognitive neuroscience of aging: Linking cognitive and cerebral aging. Oxford, Oxford University Press.

Cicchetti, D., \& Curtis, W. J. (2006) The developing brain and neural plasticity: Implications for normality, psychopathology, and resilience. New York, John Wiley \& Sons Inc.

File, B., Tóth, B., Kardos, Zs., Boha, R., Hillebrand, A., Stam C. J., Molnár M. Frequency-specific decline of anterior-posterior frontoparietal information flow with aging: EEG resting-state directed connectivity study. Közlés alatt
Hasson, U., Ghazanfar, A. A., Galantucci, B., Garrod, S., \& Keysers, C. (2012) Brain-to-brain coupling: a mechanism for creating and sharing a social world. Trends in cognitive sciences, 16(2), 114121

Ienca, M., \& Andorno, R. (2017) Towards new human rights in the age of neuroscience and neurotechnology. Life sciences, society and policy, 13(1), 5. https://doi.org/10.1186/s40504-017-0050-1

Kállai, J., Bende, I., Karádi, K., \& Racsmány, M. (2008) Bevezetés a neuropszichológiába. Budapest, Medicina Könyvkiadó Zrt.

Tóth, B., File, B., Boha, R., Kardos, Z., Hidasi, Z., Gaál, Z. A., ... \& Molnár, M. (2014). EEG network connectivity changes in mild cognitive impairment-Preliminary results. International Journal of Psychophysiology, 92(1), 1-7.

Tóth, B., Urbán, G., Háden, G. P., Márk, M., Török, M., Stam, C. J., \& Winkler, I. (2017) Large-scale network organization of EEG functional connectivity in newborn infants. Human brain mapping, 38(8), 4019-4033.

Watts, D. J., \& Strogatz, S. H. (1998) Collective dynamics of 'smallworld' networks. Nature, 393(6684), 440 . 